This Journal is available in Telkom University online Journals

Jurnal Manajemen Indonesia

\title{
Peran Stres Kerja dan Kepuasan Kerja Karyawan dalam Pengelolaan Tingkat Turnover Intention pada Karyawan Puskesmas Jasinga, Bogor
}

\author{
Arif Partono Prasetio ${ }^{1}$, Resya Mawaranti ${ }^{2}$, dan Erni Martini ${ }^{3}$ \\ ${ }^{1,2,3}$ School of Economics and Business, Telkom University, Bandung, Indonesia
}

\begin{abstract}
Employees who worked in health service experienced various pressures when doing their job. This is because they have to deal with various problems (diseases and treatments). Such condition could affect and even reduce their job satisfaction and in the end also affect their intention to quit. This study analyzed the effect of stress and job satisfaction on employee turnover rate at Puskesmas Jasinga, Bogor. The number of participants in this study was 108 employees. Explanatory methods and mediation analysis are used to explain the relationship and influence between variables. The results showed that employee's stress level did not have significant influence on job satisfaction, but stress significantly affected employees' intention to quit. Furthermore, no significant effect of job satisfaction on the desire to resign to employees.
\end{abstract}

Keywords-Works Stress; Job Satisfaction; Turnover Intention.

\begin{abstract}
Abstrak
Karyawan di bidang kesehatan khususnya puskesmas mengalami berbagai tekanan dalam menjalankan pekerjaannya. Hal ini dikarenakan masalah (penyakit dan perawatan) yang dihadapi relatif beragam. Kondisi tersebut diduga dapat mengurangi kepuasan kerja dan pada akhirnya bisa berakibat pada meningkatnya niat untuk mengundurkan diri. Penelitian ini menganalisis pengaruh stres dan kepuasan kerja terhadap tingkat turnover karyawan di Puskesmas Jasinga, Bogor. Jumlah responden yang berpartisipasi dalam penelitian ini adalah 108 orang. Metode eksplanatori dan analisis mediasi digunakan untuk menjelaskan hubungan dan pengaruh antar variabel. Hasil penelitian memperlihatkan bahwa tingkat stres karyawan tidak memiliki pengaruh signifikan terhadap kepuasan kerja, akan tetapi stres secara signifikan positif mempengaruhi niat karyawan untuk mengundurkan diri. Selanjutnya, tidak ditemukan pengaruh signifikan dari kepuasan kerja terhadap keinginan untuk mengundurkan diri pada karyawan.
\end{abstract}

Kata kunci-Stres Kerja; Kepuasan Kerja; Turnover Intention.

\section{PENDAhUluan}

Peran sumberdaya manusia dalam mendukung keberhasilan suatu organisasi sudah diakui (Baldaia, 2011; Skroupa, 2017; dan Ferres, 2015). Sumberdaya manusia yang berkualitas berdampak positif terhadap kinerja dan kemajuan suatu organisasi (Brury, 2016). Keberhasilan organisasi dalam mencapai sasaran sangat dipengaruhi oleh bagaimana mereka mengelola sumberdaya manusianya. Organisasi yang menggunakan tenaga kerja manusia akan mengalami kondisi yang sama. Apalagi dalam industri yang menangani layanan kesehatan. Sumberdaya manusia memegang peranan penting dalam memberikan layanan informasi dan perawatan kesehatan kepada kosnumen (pasien). Salah satu tolok ukur bahwa organisasi telah mengelola sumberdaya manusia dengan baik adalah dengan melihat pada tingkat perputaran karyawan atau yang dikenal dengan istilah Turnover. Tingkat perputaran yang rendah mengindikasikan karyawan nyaman bekerja di dalam organisasi tersebut. Membahas turnover yang merupakan perilaku yang sudah dilakukan, dapat diawali dengan mengkaji apakah terdapat niatan untuk mengundurkan diri. Kemunculan niat ini dapat menjadi indikasi besar atau kecilnya karyawan yang akan mundur. Organisasi perlu mengindentifikasi seberapa besar niat untuk

\section{Article info}

Received ( $9^{\text {th }}$ April, 2018)

Revised (2 ${ }^{\text {nd }}$ May, 2018)

Accepted (26 $6^{\text {th }}$ July, 2018)

Corresponding_author: ${ }^{1}$ Partono67@gmail.com, 
mengundurkan diri ini berkembang dalam diri karyawan. Niat untuk mengundurkan diri atau yang dikenal dengan Turnover Intention (TI) perlu dikendalikan karena merupakan masalah serius (Fah et al., 2010). Sanborn (2017) menyatakan bahwa kerugian yang dialami oleh industri kesehatan terkait pengunduran diri karyawan dapat mencapai 27 juta US Dollar. Di samping itu terdapat kemungkinan kerugian lain jika dikaitkan dengan potensi turunnya kualitas layanan, produktivitas, dan kepuasan konsumen. Kehilangan karyawan berpotensi dapat mempengaruhi kinerja organisasi.

Tingkat TI dalam suatu organisasi dipengaruhi oleh berbagai faktor. Salah satu faktor yang dinilai memiliki kaitan dengan TI adalah proses rekrutmen dan seleksi yang diselenggarakan oleh perusahaan (Sanborn, 2017). Faktor lain yang diketahui memiliki peran dalam mengurangi atau menambah tingkat TI adalah ketidakjelasan peran atau pekerjaan, pengembangan karier yang tidak prospektif, engagement, kepuasan kerja, komitmen organisasi, persepsi karyawan atas dukungan organisasi, tingkat pendapatan, keeratan hubungan dengan rekan kerja, gaya kepemimpinan, dan beban kerja (Prahadi, 2015; Dwyer, 2014; Suliman \& Al-Junaibi, 2010; Addae et al., 2006; Hussain \& Asif, 2012; Liu et al., 2013; Tuzun \& Kalemci, 2012; Khan \& Du, 2014; De Clercq et al., 2017; Raza et al., 2017; Liu \& Onwuegbuzie, 2012).

Mosadeghrad (2013) mengatakan bahwa stres kerja dapat mempengaruhi tingkat kepuasan kerja dan komitmen karyawan terhadap organisasi, yang selanjutnya berdampak pada niat untuk keluar. Pandangan tersebut dikuatkan oleh penelitian terdahulu. Penelitian oleh Mxenge et al. (2014) di Afrika Selatan dan Lin et al. (2013) di China menemukan arah hubungan positif antara stres dan TI. Di samping itu, terkait kepuasan kerja, studi yang dilakukan oleh Mahdi et al. (2012) di Malaysia, Yamazakia \& Petchdee (2015) di Thailand, dan De Moura et al. (2009) di Jepang dan Inggris menemukan hubungan negatif antara kepuasan kerja dan TI. Penelitian ini menganalisis peran stres kerja dan kepuasan kerja yang dialami karyawan Puskesmas Jasinga di Bogor dan pengaruhnya terhadap tingkat TI. Unsur kepuasan kerja akan dikaji apakah memiliki peran sebagai mediasi dalam hubungan antara stres dan TI. Puskesmas Jasinga merupakan sebuah organisasi yang bergerak di layanan kesehatan. Tenaga kesehatan memiliki kemampuan dan wewenang dalam memberikan asuhan keperawatan berdasarkan bidang keilmuannya. Beban yang dimiliki pekerjaan ini mampu menyebabkan tekanan pada setiap pegawai dan akan menimbulkan stres serta dapat terjadinya ketidakpuasan pada pegawai. Penelitian ini diharapkan dapat memberikan manfaat bagi organisasi dalam mengendalikan tingkat stres yang mungkin dialami karyawan serta membangun suasan kerja positif untuk meningkatkan kepuasan kerja sehingga organisasi dapat mempertahankan sumberdaya manusia yang terbaik.

\section{KAJIAN Literatur DAN PENGEMbangan HiPOTESIS}

\section{A. Stres dan Kepuasan Kerja}

Penelitian mengenai stres dan pengaruhnya terhadap tingkat kepuasan kerja sudah banyak dilakukan di berbagai negara. Stres kerja didefinisikan Robbins \& Judge (2017) suatu kondisi dinamis dimana individu dihadapkan pada suatu peluang, tuntutan, atau sumberdaya yang berhubungan dengan kepentingan individu terkait dan hasilnya nantinya diperoleh dinilai penting akan tetapi belum memiliki kepastian. Kondisi ini biasanya menyebabkan ketidaknyamanan psikologis yang ditimbulkan dengan adanya tekanan dari lingkungan. Sedangkan kepuasan kerja merupakan suatu perasaan positif dari individu (karyawan) terkait pekerjaan yang dilakukan dimana persepsi tersebut didapatkan melalui serangkaian evaluasi terhadap seluruh aspek pekerjaannya (Robbins \& Judge, 2017). Stres kerja yang diakibatkan oleh beban kerja serta tenggat waktu yang mendesak dapat menyebabkan berkurangnya kepuasan kerja. Tidak itu saja, stres berkepanjangan dapat menghambat kinerja individu dan organisasi. Studi oleh Khan et al. (2014) menemukan adanya dampak negatif dari stres terhadap kepuasan kerja. Selanjutnya, penelitian dengan responden dari kalangan kademisi di Malaysia oleh Ahsan et al. (2014) menegaskan adanya hubungan signifikan negatif antara stres dengan kepuasan kerja. Penelitian terdahulu juga membahas berbagai aspek dari stres kerja dikaitkan dengan kepuasan kerja. Love et al. (2010) di Amerika Serikat meneliti dampak beban pekerjaan terhadap kepuasan kerja dan menemukan adanya hubungan negatif. Selanjutnya Chen et al. (2007) di Taiwan mengemukakan adanya pengaruh negatif dari ketidakjelasan peran serta beban kerja yang berlebihan terhadap tingkat kepuasan kerja karyawan di bidang kesehatan. Ejaz et al. (2008) melakukan penelitian di Amerika Serikat dengan menggunakan responden dari kalangan Care Worker menemukan pengaruh negatif stres kerja dan stres personal dengan tingkat kepuasan kerja. Sedangkan Noelker et al. (2006) juga di Amerika Serikat menemukan hubungan yang sama dengan menggunakan responden dari kalangan asisten perawat. Penelitian lain yang menemukan arah negatif dalam hubungan stres dengan kepuasan kerja adalah Tongchaiprasit \& Ariyabuddhiphongs (2016) 
di Thailand, Iqbal \& Waseem (2012) dan Mansoor et al. (2011) di Pakistan, Lu et al. (2007) di Taiwan, Duraisingam et al. (2009), Australia, Khamisa et al. (2017), Afrika Selatan, Anton (2009) di Spanyol, Venkataraman \& Ganapathi (2013) dan Kumar (2011) di India, serta Li et al. (2014) di China. Berdasarkan temuan dari penelitian terdahulu, maka penelitian ini menentukan hipotesis sebagai berikut;

$\boldsymbol{H}_{1}$ : stress kerja memiliki pengaruh signifikan negatif terhadap kepuasan kerja karyawan.

\section{B. Stres dan Turnover Intention}

Disamping menyebabkan menurunnya kepuasan kerja, stres dapat berdampak terhadap munculnya niat karyawan untuk mundur (turnover intention). Turnover dijelaskan oleh Dessler (2013) sebagai tingkat pengunduran diri karyawan. Snell \& Bohlander (2013) mendefinisikannya sebagai pergerakan karyawan keluar dari perusahaan. Berdasarkan definisi tersebut, muncul istilah Turnover Intention (TI) yang dijelaskan oleh Branham (2012) sebagai kecenderungan sikap karyawan untuk keluar atau mencari peluang baru. TI berbeda dengan turnover karena pada tingkatan TI, masih sebatas pada adanya unsur kecenderungan (niat). Dengan memahami TI peneliti dapat mengidentifikasi sejauh mana niatan karyawan untuk mencari pekerjaan baru atau untuk meninggalkan perusahaan dalam jangka waktu tertentu. Di dalam pengertian tersebut terkandung unsur niat yang diartikan bahwa karyawan mengundurkan diri karena keinginan sendiri. Berbagai faktor bisa menjadi penyebab meningkatnya TI. Beberapa di antaranya adalah tingkat komitmen organisasional, kepuasan kerja, lingkungan kerja, stres kerja, beban kerja (Qureshi et al., 2013; Mxenge et al., 2014; Sutanto \& Gunawan, 2013). Karyawan yang merasa tidak nyaman bekerja akan memiliki kecenderungan untuk keluar lebih besar. Salah satu penyebab ketidaknyamanan bekerja adalah stres karena pekerjaan. Penelitian yang mempelajari hubungan dan pengaruh stres terhadap TI sudah banyak dilakukan. Sebagian besar dari studi tersebut menemukan adanya hubungan positif antara tingkat stres dan TI. Karyawan yang memiliki atau merasakan stres kerja yang tinggi dalam bekerja memiliki niat untuk mundur lebih besar. Mxenge et al. (2014) mendukung pandangan tersebut dengan hasil penelitian di Afrika Selatan. Studi dari China oleh Lin et al. (2013) juga mengemukakan adanya hubungan antara stres dan TI. Selanjutnya, penelitian menggunakan perawat sebagai responden di Iran menegaskan adanya hubungan positif antara stres kerja dan TI (Ahanian et al., 2016). Penelitian dengan latar belakang budaya barat oleh Jaramillo et al. (2006) menyampaikan temuan bahwa ketidakjelasan peran dapat meningkatkan stres yang pada akhirnya dapat memperbesar niat karyawan untuk mengundurkan diri. Penelitian lain di Korea menggunakan responden karyawan hotel berbintang dan rumah sakit mendukung temuan bahwa stres terkait pekerjaan dapat meramalkan niat karyawan untuk keluar (Hwang et al., 2014; Yim et al., 2017). Studi oleh Tongchaiprasit \& Ariyabuddhiphongs (2016) di Thailand, Sewwandi \& Perere (2016) di Srilanka, Raza et al. (2017), Javed et al. (2014), dan Tziner et al. (2015) di Israel menyajikan temuan hubungan positif antara stres dan TI. Berdasarkan temuan dari beragam studi, kami menetapkan hipotesis untuk hubungan antara stres dan TI adalah;

\section{$\boldsymbol{H}_{2}$ : stres kerja memiliki pengaruh signifikan positif terhadap turnover intention.}

\section{Kepuasan Kerja dan Turnover Intention}

Merupakan salah satu kewajiban organisasi untuk memastikan bahwa karyawan yang bekerja merasakan kepuasan kerja yang baik. Karyawan yang merasakan bahwa perusahaan memperhatikan kenyamanan mereka dalam bekerja akan memberikan imbal balik positif. Salah satu bentuk imbal balik positif tersebut adalah keinginan mereka untuk bertahan di dalam organisasi. Robbins \& Judge (2017) menguatkan pernyataan tersebut dengan menyebutkan bahwa ketika karyawan sudah merasa tidak senang dengan pekerjaan mereka, salah satu responnya adalah keluar. Beragam studi telah membahas hubungan antara kepuasan kerja dengan TI dan ratarata menunjukkan hasil adanya hubungan negatif antara kedua variabel. Ketika kepuasan kerja karyawan meningkat, maka niat untuk mundur berkurang (rendah). Penelitian di Malaysia oleh Mahdi et al. (2012) dengan responden karyawan percetakan menemukan hubungan terbalik (negatif) antara aspek intrinsik dan ekstrinsik dari kepuasan kerja dengan TI. Penelitian dengan menggunakan responden dari karyawan berlatar belakang teknologi informasi di Amerika Serikat dan Srilanka memperlihatkan hubungan negatif antara kepuasan kerja dengan TI (Westlund \& Hannon, 2008; dan Wickramasinghe, 2010). Raza et al. (2017) dan Tnay et al. (2013) yang melakukan studi di Pakistan dan Malaysia menemukan bahwa kepuasan terhadap gaji berkorelasi negatif dengan niat untuk mundur. Apabila karyawan merasa puas dengan pendapatan maka niat untuk mundur berkurang. Selanjutnya beragam hasil penelitian mendukung temuan adanya hubungan negatif antara kepuasan kerja dengan TI antara lain adalah Sutanto \& Gunawan (2013) di Indonesia, Elanain (2010) di Uni Emirat Arab, Nadiri \& Tanova (2010) di Siprus, Yamazakia \& Petchdee (2015) serta Tongchaiprasit \& Ariyabuddhiphongs (2016) di Thailand, Alniacik et al. (2013) di Turki, Parry (2008) dan Duraisingam et al. (2009) di Australia, 
Valentine et al. (2011) dan Jaramilo et al. (2006) di Amerika Serikat, Anton (2009) di Spanyol, De Moura et al. (2009) di Jepang \& AS, dan Lin et al. (2013) di China. Penelitian-penelitian tersebut menguatkan temuan adanya hubungan negatif antara kepuasan kerja dengan TI. Meski sebagian besar studi menunjukkan hubungan negatif, akan tetapi setidaknya ada satu penelitian dari Nigeria oleh Olawale et al. (2016) yag menemukan hubungan positif antara kepuasan kerja dan TI. Meski demikian, dikarenakan sebagian besar hasil memperlihatkan hubungan terbalik, maka penulis menetapkan hipotesis ketiga sebagai berikut;

\section{$\boldsymbol{H}_{3}$ : Kepuasan kerja memiliki pengaruh signifikan negatif terhadap turnover intention.}

Setelah mempelajari bahwa ketiga variabel memiliki keterhubungan, penelitian ini menentukan hipotesis berikutnya terkait peran mediasi dari variabel kepuasan kerja dalam hubungan antara stres dengan TI. Didasarkan pada keterhubungan tersebut, hipotesis ke empat penelitian ini adalah;

$\boldsymbol{H}_{4}$ : Kepuasan kerja memiliki peran sebagai mediasi dalam hubungan antara stres kerja dan turnover intention.

\section{Metode PENELITIAN}

\section{A. Responden}

Penelitian ini dilakukan menggunakan responden sebanyak 108 karyawan di Puskesmas Jasinga, Bogor. Tabel 1 memperlihatkan profil responden secara detail. Data memperlihatkan bahwa distribusi pria dan wanita relatif berimbang. Untuk rentang usia karyawan terlihat bahwa rentang antara 25 - 30 tahun merupakan yang terbanyak. Kondisi ini dapat dijelaskan karena sifat pekerjaan di pusat kesehatan ini memerlukan banyak tenaga yang masih muda. Sebagian besar karyawan juga sudah menikah (62\%). Sedangkan dari sisi pengalaman bekerja, sesuai dengan usia yang relatif masih muda tadi persentase terbesar berada pada kisaran pengalaman 1 - 3 tahun (49\%). Adapun latar belakang pendidikan didominasi oleh lulusan diploma. Kondisi ini dapat dikaitkan dengan kebutuhan pekerja di pusat kesehatan masyarakat lebih banyak dari lulusan diploma kesehatan (untuk pekerjaan perawat atau asisten dokter). Hal lain yang perlu diperhatikan adalah terkait jam kerja yang menunjukkan bahwa sebagian besar karyawan bekerja lebih dari 9 jam per hari (60\%).

Table 1. Profil Responden

\begin{tabular}{|c|c|c|c|c|c|}
\hline Demografis & Frekuensi & Persentase & Demografis & Frekuensi & Persentase \\
\hline Jenis Kelamin & & & Masa Kerja & & \\
\hline Pria & 45 & $42 \%$ & $<1$ tahun & 16 & $15 \%$ \\
\hline Wanita & 63 & $58 \%$ & $1-3$ tahun & 53 & $49 \%$ \\
\hline Rentang Usia & & & $>3-5$ tahun & 14 & $13 \%$ \\
\hline$<25$ & 23 & $21 \%$ & $>5-10$ tahun & 21 & $19 \%$ \\
\hline $25-30$ & 49 & $45 \%$ & $>10$ tahun & 4 & $4 \%$ \\
\hline$>30-35$ & 9 & $8 \%$ & Pendidikan & & \\
\hline$>35-40$ & 17 & $16 \%$ & SMA/SMK & 14 & $13 \%$ \\
\hline$>40-45$ & 9 & $8 \%$ & Diploma & 68 & $63 \%$ \\
\hline$>45-50$ & 0 & $0 \%$ & S1 & 25 & $23 \%$ \\
\hline$>50$ & 1 & $1 \%$ & S2 & 1 & $1 \%$ \\
\hline Status Keluarga & & & $\mathrm{S} 3$ & 0 & $0 \%$ \\
\hline Menikah & 67 & $62 \%$ & Lama Kerja dlm 1 Hari & & \\
\hline Belum Menikah & 37 & $34 \%$ & Sampai dengan 9 jam & 40 & $37 \%$ \\
\hline Cerai & 4 & $4 \%$ & Lebih dari 9 jam & 68 & $63 \%$ \\
\hline
\end{tabular}

\section{B. Teknik Analisis Data}

Penelitian ini menganalisis hubungan antara stres dengan TI serta peran kepuasan kerja sebagai mediasi dalam hubungan tersebut. Analisis data dilakukan menggunakan SPSS untuk menghitung korelasi antar variabel. Selanjutnya untuk melihat pengaruh stres terhadap TI dan unsur mediasi dari kepuasan kerja, digunakan pendekatan bootstrapping menggunakan PROCESS Macro (Hayes, 2013). Teknik ini dinilai tepat 
untuk menganalisis pengaruh antar variabel sekaligus menentukan adanya unsur mediasi karena menghindari keharusan memenuhi asumsi normalitas terkait distribusi sampel melalui penerapan bootstrapping confidence intervals (Preacher et al., 2007). Unsur mediasi dari kepuasan kerja akan ditentukan berdasarkan nilai Upperlevel dan Lowerlevel Confidence Interval yang tidak mengandung angka 0.

\section{Alat Ukur}

Data penelitian diperoleh dengan melakukan survei langsung lokasi organisasi. Pengumpulan data dilakuan menggunakan kuesioner yang berisi 34 butir pertanyaan terkait kepuasan kerja, stres, dan TI. Pertanyaan mengenai kepuasan kerja terdiri dari 20 butir yag dikembangkan berdasarkan konsep dari Robbins \& Judge (2017). Pertanyaan untuk mengidentifikasi stres ada 8 butir yang dikembangkan dari Elci et al. (2012). Terakhir, 6 butir pertanyaan mengenai TI juga dikembangkan berdasarkan penelitian Elci et al. (2012). Nilai cronbach alpha untuk masing-masing variabel adalah 0,949 (kepuasan kerja), 0,929 (stres), dan 0,896 (TI). Berdasrkan skala Likert, masing-masing butir pertanyaan diberikan 6 alternatif pilihan jawaban dari 1 (sangat tidak setuju) hingga 6 (sangat setuju). Penelitian ini menggunakan 6 skala untuk menghindari jawaban tengah dari responden. Jawaban tengan (ragu-ragu) dibagi menjadi 2, ragu-ragu cenderung tidak setuju (3) dan ragu-ragu cenderung setuju (4).

\section{HASIL DAN PEMBAHASAN}

Tabel 2 memperlihatkan means, standar deviasi, dan korelasi antar variabel. Berdasarkan tabel tersebut diketahui bahwa kepuasan kerja memiliki korelasi dengan TI sebesar -0,210 yang tergolong lemah. Akan tetapi kepuasan kerja ditemukan tidak memiliki hubungan dengan stres. Sedangkan untuk korelasi antara stres dan TI diketahui signifikan dengan arah positif. Nilai korelasi untuk stres dan TI sebesar 0,658 yang menurut Wegner (2016) dikategorikan sebagai hubungan yang kuat karena mendekati nilai satu. Sedangkan menurut Rumsey (2011) nilai tersebut tergolong korelasi yang menengah.

Table 2. Mean, Standar Deviasi, \& Korelasi

\begin{tabular}{lcllll}
\hline & Mean & SD & Stres & Kepuasan & Turnover \\
\hline Stres & 2.3156 & .93983 & & & \\
Kepuasan & 4.6588 & .77302 & -.092 & & \\
Turnover & 2.2329 & .93308 & $\mathbf{. 6 5 8} * *$ & $\mathbf{- . 2 1 0 *}$ & \\
\hline **. Signifikansi korelasi 0.01 level (2-tailed). & & & \\
*. Signifikansi korelasi 0.05 level (2-tailed). & & &
\end{tabular}

Pembahasan selanjutnya terkait analisis mediasi mengacu pada Tabel 3. Nilai koefisien stres terhadap kepuasan kerja adalah -0,076 dengan nilai $p>0,05$. Hal ini menunjukkan bahwa karyawan yang mengalami stres tidak berdampak pada tingkat kepuasan kerjanya. Sedangkan nilai koefisien kepuasan kerja terhadap TI sebesar $-0,181$ dengan nilai $p<0,05(0.041)$. Kepuasan kerja memiliki pengaruh signifikan negatif (meski sangat lemah) terhadap niat karyawan untuk mengundurkan diri. Selanjutnya, nilai koefisien stres dengan TI sebeasr 0,640 dengan $p<0,05(0,000)$, hal ini menunjukkan bahwa karyawan dengan tingkat stres akan mengalami peningkatan terkait niat atau rencana mereka untuk keluar.

Table 3. Regression coefficient, Standard error, \& Model Summary

\begin{tabular}{lcccccc}
\hline & \multicolumn{3}{c}{ Kepuasan Kerja } & \multicolumn{3}{c}{ Turnover } \\
& Coeff & SE & p-value & Coeff & SE & p-value \\
\hline Stres & -0.076 & 0.080 & 0.341 & 0.640 & 0.072 & 0.000 \\
Kepuasan Kerja & - & - & - & -0.181 & 0.087 & 0.041 \\
Constant & 4.835 & 0.199 & 0.000 & 1.596 & 0.458 & 0.000 \\
\cline { 2 - 7 } & \multicolumn{2}{c}{ R Square } & 0.009 & R Square & 0.455 \\
& \multicolumn{2}{c}{ F $=$} & 0.913 & F $=$ & 43.867 \\
& \multicolumn{2}{c}{$\mathrm{p}=$} & 0.341 & $\mathrm{p}=$ & 0.000 \\
\hline
\end{tabular}


Untuk menganalisis hipotesis dalam penelitian ini digunakan SPSS dengan tambahan program PROCESS (Hayes, 2013). Hipotesis pertama yaitu stres memiliki pengaruh signifikan negatif terhadap kepuasan kerja $\left(\mathrm{H}_{1}\right)$ ternyata tidak diterima. Hasil penelitian menunjukkan bahwa tidak ada pengaruh signifikan dari stres terhadap tingkat kepuasan kerja (nilai koefisien - KO: -0,076, standar error - SE: 0,080, \& p: 0,341). Hipotesis kedua, yaitu ada pengaruh signifikan positif dari stres terhadap TI $\left(\mathrm{H}_{2}\right)$ diterima. Stres yang dialami karyawan dapat meningkatkan pemikiran atau rencana untuk keluar dari organisasi (KO: 0,640, SE: 0,072, p: 0,000). Hipotesis ketiga yaitu adanya hubungan pengaruh negatif antara kepuasan kerja terhadap TI diterima (KO: -0,181, SE: 0,087, p: 0,041). Kepuasan kerja karyawan dapat mempengaruhi niat mereka untuk mundur. Keterkaitan antara variabel disajikan pada Gambar 1.

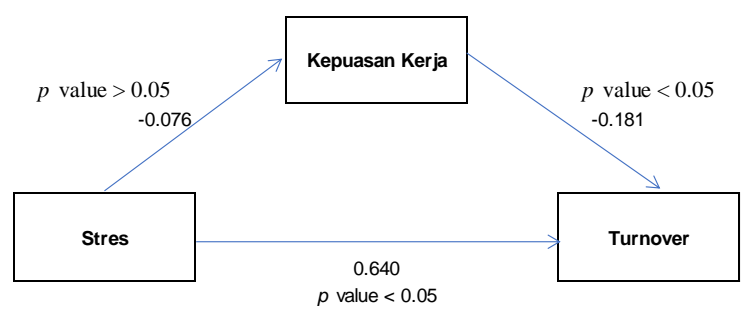

Gambar 1. Model Mediasi Kepuasan Kerja

Menganalisis ada atau tidaknya unsur mediasi dari satu variabel menggunakan PROCESS dilakukan dengan melihat apakah di dalam nilai Lower Level Confidence Interval (LLCI) dan Upper Level Confidence Interval (ULCI) terdapat angka 0 atau tidak. Apabila ditemukan ada nilai 0, maka variabel yang dianalisis dikatakan tidak memiliki peran mediasi. Dengan demikian nilai LLCI dan ULCI harus positif atau negatif. Nilai positif berarti variabel terkait memiliki peran positif (searah), sebaliknya nilai negatif memperlihatkan adanya peran berlawanan. Tabel 4 memperlihatkan hasil perhitungan yang dilakukan dan sekaligus menjadi dasar untuk menjawab hipotesis ke empat $\left(\mathrm{H}_{4}\right)$ terkait peran kepuasan kerja dalam memediasi hubungan antara stres dan TI. Diketahui bahwa nilai LLCI dan ULCI ternyata mengandur unsur 0, dengan demikian hipotesis 4 ditolak. Kepuasan kerja tidak memiliki peran dalam memediasi hubungan pengaruh antara stres dan TI.

Table 4. Pengaruh Tidak Langsung Melalui Kepuasan Kerja

Pengaruh Tidak Langsung Stres Terhadap Turnover

\begin{tabular}{ccccc}
\hline & Effect & Boot SE & BootLLCI BootULCI \\
\hline Melalui Kepuasan Kerja & 0.014 & 0.019 & -0.009 & 0.077
\end{tabular}

Penelitian ini menemukan bahwa tingkat stres karyawan di dalam organisasi tersebut tergolong rendah, sedangkan kepuasan kerja mereka tergolong tinggi, dan niat mereka untuk berganti atau pindah ke perusahaan lain juga rendah. Dapat dikatakan karyawan dalam organisasi tersebut telah merasakan kondisi yang nyaman atau setidaknya sesuai dengan harapan mereka. Pekerjaan mereka di Puskesmas relatif membuat mereka puas sehingga tidak mengakibatkan efek negatif dalam kehidupan pribadi. Karyawan yang merasa puas dan tidak mengalami tekanan berlebihan dalam pekerjaannya cenderug untuk tetap bertahan dalam organisasi. Penelitian ini mengkaji hubungan antara stres, kepuasan kerja, dan TI pada karyawan Puskesmas Jasinga di Bogor. Hasil penelitian menunjukkan bahwa stres secara langsung mempengaruhi tingkat TI. Unsur kepuasan kerja memiliki pengaruh terhadap TI karyawan akan tetapi tidak memiliki peran mediasi dalam hubungan antara stres dan TI. Hasil penelitian terkait hubungan stres dengan kepuasan kerja ternyata berlawanan dengan penelitian terdahulu yang menyatakan adanya hubungan dan pengaruh negatif dari stres terhadap kepuasan kerja karyawan. Penelitian yang dilakukan di Malaysia, Spanyol, Taiwan, Australia, Amerika Serikat, Pakistan, Afrika Selatan, India, China, Thailand, dan Yunani seluruhnya mendukung pendapat tersebut (Ahsan et al., 2009; Anton, 2009; Chen et al., 2007; Duraisingam et al., 2009; Ejaz et al., 2008; Iqbal \& Waseem, 2012; Jaramilo et al., 2006; Khamisa et al., 2017; Khan et al., 2014; Kumar, 2011; Li et al., 2014; Lin et al., 2013; Love et al., 2010; Lu et al., 2007; Venkataraman \& Ganapathi, 2013; Mansoor et al., 2011; Noelker et al., 2006; Trivellas et al., 2013; Tongchaiprasit \& Ariyabuddhiphongs, 2016). Perbedaan hasil temuan ini memunculkan pertanyaan apakah stres senantiasa terkait dengan kepuasan kerja. Meski tingkat stres karyawan di Puskesmas Jasinga tergolong rendah dan kepuasan kerja mereka tinggi, akan tetapi ternyata tingginya kepuasan kerja tidak berkorelasi dengan tingkat stres. Dengan demikian ada hal lain yang perlu dikaji oleh organisasi apabila ingin meningkatkan kepuasan 
kerja karyawan. Faktor-faktor seperti gaya kepemimpinan, pekerjaan yang menantang, pengembangan karier, serta kompensasi dapat menjadi unsur yang mempengaruhi kepuasan kerja karyawan.

Terkait hubungan antara stres dengan TI, hasil penelitian mendukung riset sebelumnya dengan responden dari berbagai industri menemukan adanya pengaruh signifikan positif. Ketika stres meningkat, karyawan mulai berpikir untuk berganti pekerjaan atau perusahaan. Keragaman latar belakang budaya terkait hasil tersebut relatif terwakili. Berbagai riset yang dilakukan di Iran, Spanyol, Australia, Korea Selatan, Amerika Serikat, Pakistan, China, Afrika Selatan, Srilanka, dan Thailand menguatkan pandangan tersebut (Ahanian et al., 2016; Anton, 2009; Duraisingam et al., 2009; Hwang et al., 2014; Jaramilo et al., 2006; Javed et al., 2014; Lin et al., 2013; Mxenge et al., 2014; Qureshi et al., 2013; Raza et al., 2017; Sewwandi \& Perere., 2016; Tongchaiprasit \& Ariyabuddhiphongs, 2016; Yim et al., 2017).

Hasil penelitian yang menganalisis hubungan dan pengaruh kepuasan kerja terhadap TI sejalan dengan riset terdahulu yang dilakukan oleh Anton, 2009; Alniacik et al., 2013; De Moura et al., 2009; Duraisingam et al., 2009; Elanain, 2010; Jaramilo et al., 2006; Lin et al., 2013; Mahdi et al., 2012; Nadiri \& Tanova, 2010; Olawale et al., 2016; Parry, 2008; Raza et al., 2017; Sutanto \& Gunawan, 2013; Tnay et al., 2013; Tongchaiprasit \& Ariyabuddhiphongs, 2016; Valentine et al., 2011; Westlund \& Hannon, 2008; Wickramasinghe, 2010; Yamazakia \& Petchdee, 2015 menemukan hubungan dan pegaruh negatif dari kepuasan kerja terhadap TI. Penelitian tersebut dilakukan di berbagai negara (Spanyol, Turki, Jepang, Amerika Serikat, Australia, Uni Emirat Arab, China, Malaysia, Siprus, Nigeria, Pakistan, Indonesia, Thailand, dan Srilanka) serta menggunakan responden dari beragam industri (layanan jasa, kesehatan, ritel pendidikan, perbankan, percetakan, hotel, produksi, dan manufaktur).

\section{KESIMPULAN}

Tiga hipotesis dalam penelitian ini terjawab dan diterima. Stres ternyata tidak berpengaruh signifikan terhadap tingkatkepuasan kerja. Akan tetapi, stres dan kepuasan kerja memiliki pengaruh positif terhadap TI. Mengingat tidak ada korelasi dan pengaruh dari stres terhadap kinerja dengan demikian, kepuasan kerja tidak memiliki peran sebagai mediasi. Hasil penelitian ini sebagain besar mendukung hasil penelitian terdahulu, kecuali temuan terkait tidak adanya hubungan antara stres dan kepuasan kerja.

Mengingat objek penelitian hanya satu organisasi di bidang layanan kesehatan dan jumlah responden yang digunakan tidak terlalu besar, hasil penelitian ini relatif sulit untuk dijadikan pedoman secara umum. Oleh karena itu masih diperlukan adanya penelitian lain dengan responden lebih banyak serta berasal dari beragam industri.

Selanjutnya sebagai masukan bagi organisasi terkait ketiak hendak meningkatkan kepuasan kerja, mereka dapat memperhatikan faktor lain yang memiliki pengaruh seperti dukungan organisasi, kesesuaian gaya kepemimpinan, dan peluang pengembangan karier. Sedangkan terkait sasaran untuk meminimalkan atau mengurangi niat karyawan untuk mengundurkan diri, manajemen dapat fokus pada tindakan atau kebijakan yang dapat meminimalkan atau membantu karyawan dalam mengelola stres. Berdasarkan hasil penelitian tingkat stres ini menjadi prediktor terbesar sehingga diyakini merupakan variabel yang perlu dikelola dengan baik untuk mencegah karyawan keluar.

\section{DAFTAR PUSTAKA}

Addae, H.M., Parboteeah, K.P., \& Davis, E.E. (2006). Organizational commitment and intentions to quit. International Journal of Organizational Analysis, Vol. 14 Iss 3 pp. 225 - 238.

Ahanian, E., Mirzae, A., \& Fardi, A.S. (2016). The Study of Correlation Between Job Sress and Turnover Intentions Among The Operating Room Nurses in Selected Hospitals of Tehren University Medical Science. Acta Medica Mediterranea, 32: 1045.

Ahsan, N., Abdullah, Z., Fie, D. Y. G., \& Alam, S. S. (2009). A Study of Job Stres on Job Satisfaction among University Staff in Malaysia: Empirical Study. European Journal of Social Sciences. 8(1), 121-131.

Alniacik, E., Alniacik, U., Erat, S. \& Akcin, K. (2013). Does Person-Organization Fit Moderate The Effects Of Affective Commitment And Job Satisfaction On Turnover Intentions. Procedia - Social and Behavioral Sciences, Vol. 99, 274-281. 
Anton, C. (2009). The impact of role stress on workers' behaviour through job satisfaction and organizational commitment. International Journal of Psychology, 44:3, 187-194, DOI: 10.1080/00207590701700511.

Baldaia, J. (2011). In The Future, The Success Of An Organizations Also Depends On Human Resource Management. www.josebaldaia.com/intuinovare/uncategorized/in-the-future-the-success-of-an-organization-also-depends-on-human-resources-management/?lang=en. Diakses 13 April 2018.

Branham, L. (2012). The 7 Hidden Reasons Employees Leave: How to Recognize The Subtle Signs and Act Before It's Too Late (2nd ed.). New York: AMACOM.

Brury, M. (2016). Pengaruh Kepemimpinan, Budaya Organisasi, Motivasi Kerja Dan Kepuasan Kerja Terhadap Kinerja Pegawai (Pada Kantor SAR Sorong). Jurnal Riset Bisnis dan Manajemen, Vol. 4 No. 1, 1-16. Retrived from e-journal UNSTRAT (Universitas Sam Ratulangi).

Chen, Y.M., Chen, S.H., Tsai, C.Y., \& LO, L.Y. (2007). Role stress and job satisfaction for nurse specialists. Journal of Advanced Nursing, 59(5), 497-509. doi: 10.1111/j.1365-2648.2007.04339.x

De Clercq, D., Belausteguigoitia, I., Cornelius, N., \& Ng, E.S. (2017). Reducing the harmful effect of role ambiguity on turnover intentions: the roles of innovation propensity, goodwill trust, and procedural justice. Personnel Review, https://doi.org/10.1108/PR-08-2015-0221.

De Moura, G.R., Abrams, D., Retter, C., Gunnarsdottir, S., \& Ando, K. (2009). Identification as an organizational anchor: How identification and job satisfaction combine to predict turnover intention. European Journal of Social Psychology, 39, 540-557.

Dessler, G. (2013). Human Resources Management, 13th Edition. New Jersey: Pearson Education Inc.

Duraisingam, V., Pidd, K., \& Roche A.M. (2009). The impact of work stress and job satisfaction on turnover intentions: A study of Australian specialist alcohol and other drug workers. Drugs: education, prevention and policy, 16(3): 217-231

Dwyer, D. (2014). Employee Compensation \& Salary Structure Causing Turnover. https://hsdmetrics.com/employee-retention/employee-compensation-salary-structure-causing-turnover/. Diakses 3 April 2018

Ejaz, F.K., Noelker, L.S., Menne, H.L., \& Bagaka's, J.G. (2008). The Impact of Stress and Support on Direct Care Workers' Job Satisfaction. The Gerontologist, Vol. 48, Special Issue I, 60-70.

Elanain, H.M.A. (2010). Testing the direct and indirect relationship between organizational justice and work outcomes in a non-Western context of the UAE. Journal of Management Development, Vol. 29, Iss 1, 527.

Elci, M., Sener, I., Aksoy, S., \& Alpkan, L. (2012). The Impact of Ethical Leadership and Leadership Effectiveness on Employee's Turnover Intention: The Mediating Role of Work Related Stress. Procedia Social and Behavioral Sciences. 58, $289-297$.

Fah, C.B., Foon, S.Y., Leong, C., \& Osman, S. (2010). An Exploratory Study on Turnover intention Among Private Sector Employee International Journal of Busniness and Management. Vol. 5, No. 8. 55-64.

Ferres, Z. (2015). The Human Element: Your Most Important Business Resource. https://www.entrepreneur.com/article/245848. Diakses 15 April 2018

Hayes, A.F. (2013). Introduction to Mediation, Moderation, and Conditional Process Analysis: A RegressionBased Approach. New York: The Gilford Press.

Hussain, T., \& Asif, S. (2012).Is Employee's Turnover Intention Driven By Organizational Commitment and Perceived Organizational Support? Journal of Quality and Technology Management, 7(2), 01-10.

Hwang, J., Lee, J.J., Park, S., Chang, H., \& Kim, S.S. (2014). The Impact of Occupational Stress on Employee's Turnover Intention in the Luxury Hotel. International Journal of Hospitality \& Tourism Administration. Vol. 15, Issue. 1, 60- 77.

Iqbal, M. \& Waseem, M.A. (2012). Impact of Job Stress on Job Satisfaction among Air Traffic Controllers of Civil Aviation Authority: An Empirical Study from Pakistan. International Journal of Human Resource Studies, Vol. 2, No. 2, 53-70.

Jaramillo, F., Mulki, J., Solomon, P. (2006). The Role of Ethical Climate on Salesperson's Role Stress, Job Attitudes, Turnover Intention, and Job Performance. Journal of Personal Selling and Sales Management. Vol. 26, Issue. 3, 271- 282.

Javed M., Khan M. A., Yasir M., Aamir S., dan Ahmed K. (2014). Effect of Role Conflict, Work Life Balance and Job Stress on Turnover Intention: Evidence from Pakistan. Journal of Basic and Applied Scientific Research. Vol. 4 No. 3, 125-133. Retrieved from Research Gate.

Khamisa, N., Peltzer, K., Ilic, D., \& Oldenburg, B. (2017). Effect of personal and work stress on burnout, job satisfaction and general health of hospital nurses in South Africa. Health Sa Gesondheid, 22, 252-258.

Khan, E.A., Aqeel, M., \& Riaz, M.A. (2014). Impact of Job Stress on Job Attitudes and Life Satisfaction in 
College Lecturers. International Journal of Information and Education Technology, Vol. 4, No. 3, 270273.

Khan, M.A.S. \& Du, J. (2014). An Empirical Study of Turnover Intentions in Call Centre Industry of Pakistan. Journal of Human Resource and Sustainability Studies, 2, 206-214.

Kumar. C.S. (2011). Job stress and job satisfaction of IT Companies employees. Management and Labour Studies. 36(1).

Li L, Hu H, Zhou H, et al. (2014). Work stress, work motivation and their effects on job satisfaction in community health workers: a cross-sectional survey in China. BMJ Open, 4:e004897. doi:10.1136/bmjopen-2014-004897.

Lin, Q.-H., Jiang, C.-Q., \& Lam, T. H. (2013). The Relationship between Occupational Stress, Burnout, and Turnover Intention among Managerial Staff from a Sino-Japanese Joint Venture in Guangzhou, China. Journal of Occupational Health. Vol. 55. 458-467.

Liu, S., \& Onwuegbuzie, A. J. (2012). Chinese teachers' work stress and their turnover intention. International Journal of Educational Research, 53, 160-170.

Liu, Z., Cai, Z., Li, J., Shi, S. \& Fang, Y. (2013). Leadership style and employee turnover intentions: a social identity perspective. Career Development International, Vol. 18 No. 3, pp. 305-324.

Love, K.M., Tatman, A.W., \& Chapman, B.P. (2010). Role stress, interrole conflict, and job satisfaction among university employees: the creation and test of a model. Journal of Employment Counseling, Vol. 47, 3037.

Lu, K.Y., Chang, L.C, \& Wu, H.L. (2007). Relationship Between Professional Commitment, Job Satisfaction, ad Work Stress in Public Health Nurses in Taiwan. Journal of Professional Nursing, Vol 23, No 2, 110 116.

Mahdi, A.F., Zin, M.Z.M., Nor, M.R.M., Sakat, A.A.S., \& Sulaiman, A. (2012). The Relationship Between Job Satisfaction and Turnover intention. American Journal Of Applied Sciences. Vo;. 9, No. 9. 1518-1526.

Mansoor, M., Fida, S., Nasir, S., Ahmad, Z. (2011). The Impact of Job Stress on Employee Job Satisfaction A Study on Telecommunication Sector of Pakistan. Journal of Business Studies Quarterly, Vol. 2, No. 3, 5056.

Mosadeghrad, A.M., (2013). Occupational Stress and Turnover Intention: Implications for Nursing Management. International Journal of Health Policy and Management, 1(2), 169-176.

Mxenge, S., M.Dywili, dan Bazana, S. (2014). Organisational Stress and Employees' Intention to Quit Amongst Administrative Personnel at The University of Fort Hare, Eastern Cape, South Africa. International Journal of Research In Social Sciences. Vol. 4, No. 5, 13-29.

Nadiri, H. \& Tanova, C. (2010). An investigation of the role of justice in turnover intentions, job satisfaction, and organizational citizenship behavior in hospitality industry. International Journal of Hospitality Management, 29, 33-41.

Noelker, L.S., Ejaz, F.K., Menne, H.L., \& Jones, J.A. (2006). The Impact of Stress and Support on Nursing Assistant Satisfaction With Supervision. The Journal of Applied Gerontology, Vol. 25 No. 4, 307-323. DOI: $10.1177 / 0733464806290935$.

Olawale, A.R., Folusollesanmi, J. \& Olarewaju, A.A. (2016). Job Satisfaction, Turnover Intention And Organizational Commitment. BVIMSR's Journal of Management Research, Vol. 8, No. 2, 102-114.

Parry, J. (2008). Intention to leave the profession: antecedents and role in nurse turnover. Journal of Advanced Nursing, 64 (2), 157-167.

Prahadi, Y.Y. (2015). Turnover Talent Tinggi, Ini Dia Pemicunya. https://swa.co.id/swa/trends/management/turnover-talent-tinggi-ini-dia-pemicunya-survei. Diakses 15 April 2018

Preacher, K.J., Rucker, D.D. and Hayes, A.F. (2007). Addressing moderated mediation hypotheses: theory, methods, and prescriptions. Multivariate Behavioral Research. Vol. 42 No. 1, pp. 185-227.

Qureshi, M. I., Iftikhar, M., Abbas, S. G., Hassan, U., Khan, K., dan Zaman, K. (2013). Relationship Between Job Stress, Workload, Environment and Employees Turnover Intentions: What We Know, What Should We Know. World Applied Sciences Journal, 23(6), 764-770.

Raza, M.A., Khan, M.M., \& Mujtaba., B.G. (2017). The Impact of Organizational Change on Employee Turnover Intention: Does Stress Play a Mediating Role?. Public Organization Review.

Robbins, S.P., \& Judge, T.A. (2017). Organizational Behavior 17th Edition. England Jersey: Pearson Education Inc.

Rumsey, D.J. (2011). Statistics For Dummies, 2nd Edition. Indiana:Wiley Publishing.

Sanborn, B.J. (2017). Cure for healthcare's high employee turnover is engagement, expert says. 
http://www.healthcarefinancenews.com/news/cure-healthcares-high-employee-turnover-engagementexpert-says. Di akses 14 April 2018.

Sewwandi, D. V. S., dan Perere, G. D. N. (2016). The Impact of Job Stress on turnover Intention: A Study of Reputed Apparel Firm in Sri Lanka, Vol. 3 No. 1, 223-229. Retrieved from Journals \& Proceedings University of Sri Jayewardenepura.

Skroupa, C.P. (2017). Human Capital-Why It's A: Critical Compenent' For Success. https://www.forbes.com/sites/christopherskroupa/2017/10/10/human-capital-why-its-a-criticalcomponent-for-success/\#295071d44291. Diakses 9 April 2018

Snell, S. \& Bohlander, G. (2013). Managing Human Resources. Mason, USA:South-Western Cengage.

Suliman, A.A. \& Al-Junaibi, Y. (2010). Commitment and turnover intention in the UAE oil industry. International Journal of Human Resource Management, Vol. 21 No. 9, 1472-1489.

Sutanto, E.M., dan Gunawan, C. (2013). Kepuasan Kerja, Komitmen Organisasional dan Turnover Intentions, Jurnal Mitra Ekonomi dan Manajemen Bisnis, 4(1), 76-88.

Tnay, E., Othman, A.E., Siong, H.C. \& Lim, S.L.O. (2013). The Influences Of Job Satisfaction And Organizational Commitment On Turnover Intention. Procedia - Social and Behavioral Sciences, Vol. 97, $201-208$.

Tongchaiprasit, P. \& Ariyabuddhiphongs, V. (2016). Creativity and turnover intention among hotel chefs: The mediating effects of job satisfaction and job stress. International Journal of Hospitality Management. Volume:55, 33-40.

Trivellas, P., Reklitisa, P., \& Platis, C. (2013). The effect of job related stress on employees' satisfaction: A survey in Health Care. Procedia - Social and Behavioral Sciences, The 2nd International Conference on Integrated Information, 73, 718 - 726. doi: 10.1016/j.sbspro.2013.02.110

Tuzun, I.K., \& Kalemci, R.A. (2012). Organizational and supervisory support in relation to employee turnover intentions. Journal of Managerial Psychology, Vol. 27 Issue: 5, 518-534.

Tziner, A., Rabenu, E., Radomski, R., Belkin, A. (2015). Work stress and turnover intentions among hospital physicians: The mediating role of burnout and work satisfaction. Journal of Work and Organizational Psychology. Vol. 31. 207-213.

Valentine, S., Godkin, L., Fleischman, G.M., \& Kidwell, R. (2011). Corporate Ethical Values, Group Creativity, Job Satisfaction and Turnover Intention: The Impact of Work Context on Work Response. Journal of Business Ethics, 98:353-372.

Venkataraman, P.S. \& Ganapathi, R. (2013). A Study of Job Stress on Job Satisfaction among the Employees of Small Scale Industries. IOSR Journal of Business and Management (IOSR-JBM), Vol. 13, Issue 3, 18-22.

Wegner, T. (2016). Applied Business Statistics Methods and Excel-based Applications, 4th Edition. Cape Town: Juta \& Company Ltd.

Westlund, S.G. \& Hannon, J.C. (2008). Retaining Talent: Assessing Job Satisfaction Facets Most Significantly Related to Software Developer Turnover Intention. Journal of Information Technology Management, Vol. XIX, No. 4.

Wickramasinghe, V. (2010). Impact of time demands of work on job satisfaction and turnover intention: Software developers in offshore outsourced software development firms in Sri Lanka. Strategic Outsourcing: An International Journal, Vol. 3, Issue: 3, 246-255.

Yamazakia, Y., \& Petchdee, S. (2015). Turnover intention, Organizational Commitmen, and Specific Job Satisfaction Among Production Employees in Thailand. Journal of Business and Management. Vol. 4, No.4. 22-38.

Yim, H., Seo, H., Cho, Y., \& Kim, J. (2017). Mediating Role of Psychoogical Capital in Relationship between Occupational Stress and Turnover Intention among Nurses at Veterans Administration Hospitals in Korea. Asian Nursing Research, Vol. 11, 6-12. Retrieved from Asian Nursing Research. 